Check for updates

Cite this: RSC Adv., 2020, 10, 19790

\section{Nature as a treasure trove of potential anti-SARS- CoV drug leads: a structural/mechanistic rationale $\uparrow$}

\author{
Ahmed M. Sayed, ${ }^{a}$ Amira R. Khattab, ${ }^{\text {b }}$ Asmaa M. AboulMagd, (D) ${ }^{c}$ \\ Hossam M. Hassan, (DD de Mostafa E. Rateb, ${ }^{f}$ Hala Zaid ${ }^{g}$ \\ and Usama Ramadan Abdelmohsen (D) *hi
}

Received 11th May 2020

Accepted 21st May 2020

DOI: 10.1039/d0ra04199h

rsc.li/rsc-advances

\begin{abstract}
The novel Coronavirus disease 2019 (COVID-19) caused by SARS-CoV-2 is a potential factor for fatal illness and a tremendous concern for global public health. The COVID-19 pandemic has entered a dangerous new phase. In the context of drug discovery, the structurally-unique and chemically-diverse natural products have been valuable sources for drug leads. In this review, we report for potential candidates derived from natural sources with well-reported in vitro efficacy against SARS-CoV during the last decade. Additionally, a library of 496 phenolic metabolites was subjected to a computer-aided virtual screening

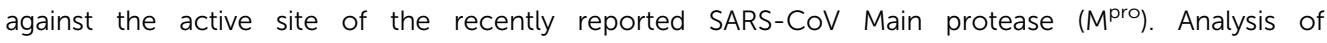
physicochemical properties of these natural products has been carried out and presented for all the tested phenolic metabolites. Only three of the top candidates, viz. acetylglucopetunidin (31), isoxanthohumol (32) and ellagic acid (33), which are widely available in many edible fruits, obey both Lipinski's and Veber's rules of drug-likeness and thus possess high degrees of predicted bioavailability. These natural products are suggested as potential drug candidates for the development of anti-SARSCoV-2 therapeutics in the near future.
\end{abstract}

\section{Introduction}

Severe Acute Respiratory Syndrome Corona Virus (SARS-CoV) is rapidly re-evolving and causing a global outbreak named "COVID-19" that is threatening hundreds of thousands of people all over the world. Similar outbreaks with the first wave of SARS-CoV emerged in southern China in 2002. In 2012, another coronavirus outbreak emerged in Jeddah, Saudi Arabia and spread within and beyond the Middle East. A Middle East

aDepartment of Pharmacognosy, Faculty of Pharmacy, Nahda University, 62513 Beni-Suef, Egypt

${ }^{b}$ Pharmacognosy Department, College of Pharmacy, Arab Academy for Science, Technology and Maritime Transport, 1029 Alexandria, Egypt

'Pharmaceutical Chemistry Department, Faculty of Pharmacy, Nahda University, 62513 Beni Suef, Egypt

${ }^{d}$ Department of Pharmacognosy, Faculty of Pharmacy, Beni-Suef University, 62514 Beni-Suef, Egypt

${ }^{e}$ Department of Pharmacognosy, Faculty of Pharmacy, Nahda University, 62513 BeniSuef, Egypt

${ }^{f}$ School of Computing, Engineering \& Physical Sciences, University of the West of Scotland, Paisley PA1 2BE, UK

${ }^{g}$ Ministry of Health and Population, Cairo, Egypt

${ }^{h}$ Department of Pharmacognosy, Faculty of Pharmacy, Minia University, 61519 Minia, Egypt. E-mail: usama.ramadan@mu.edu.eg; Tel: +2-86-2347759

${ }^{i}$ Department of Pharmacognosy, Faculty of Pharmacy, Deraya University, Universities Zone, P. O. Box 61111 New Minia City, Minia, Egypt

$\dagger$ Electronic supplementary information (ESI) available. See DOI: 10.1039/d0ra04199h respiratory syndrome caused by coronavirus (MERS-CoV) was reported this time to be associated with severe pneumonia and multi-organ failure. ${ }^{1}$ A timeline depicting the reported SARSCoV-2 outbreaks is shown in Fig. 1A. Etiologically, SARS-CoV belongs to the genus Coronaviridae, a positive strand family. The enveloped RNA viruses have a membrane comprising four viral proteins i.e. spike glycoprotein (S), membrane glycoprotein $(\mathrm{M})$, nucleocapsid proteins $(\mathrm{N})$ and an envelope protein $(\mathrm{E})$ (Fig. 1B). These proteins function during host cell entry and viral morphogenesis and release S-glycoprotein on the surface of the virus, which is responsible for virus attachment to a host receptor named ACE-II. ${ }^{2}$

SARS-CoV genome is predominated by two open reading frames that are connected by a ribosomal frameshift site, and that encode two replicase proteins, viz. pp1a and pp1ab. ${ }^{3} \mathrm{pp} 1 \mathrm{a}$ and $\mathrm{pp} 1 \mathrm{~b}$ produce viral functional proteins via proteolytic process performed by the aid of two proteases i.e. papain-like cysteine protease $\left(\mathrm{PL}^{\mathrm{pro}}\right)$ and chemotrypsin-like cysteine protease $\left(3 \mathrm{CL}^{\mathrm{pro}}\right)$. The latter is also called Main protease $\left(\mathrm{M}^{\mathrm{pro}}\right)$, which is vital to the viral replication and virulence. ${ }^{4}$

We aimed in this review to compile an updated knowledge on the natural products with proven in vitro anti-SARS CoV reported during the period from 2005 till the beginning of 2020 . We searched PubMed and Google Scholar for English language articles published without start date restrictions up to April $15^{\text {th }}$ 2020 with the keywords: "anti-SARS CoV", "natural products as $\mathrm{M}^{\text {pro }}$, $\mathrm{PL}^{\text {pro }}$, ACE2-S-protein, helicase inhibitors”, "natural 


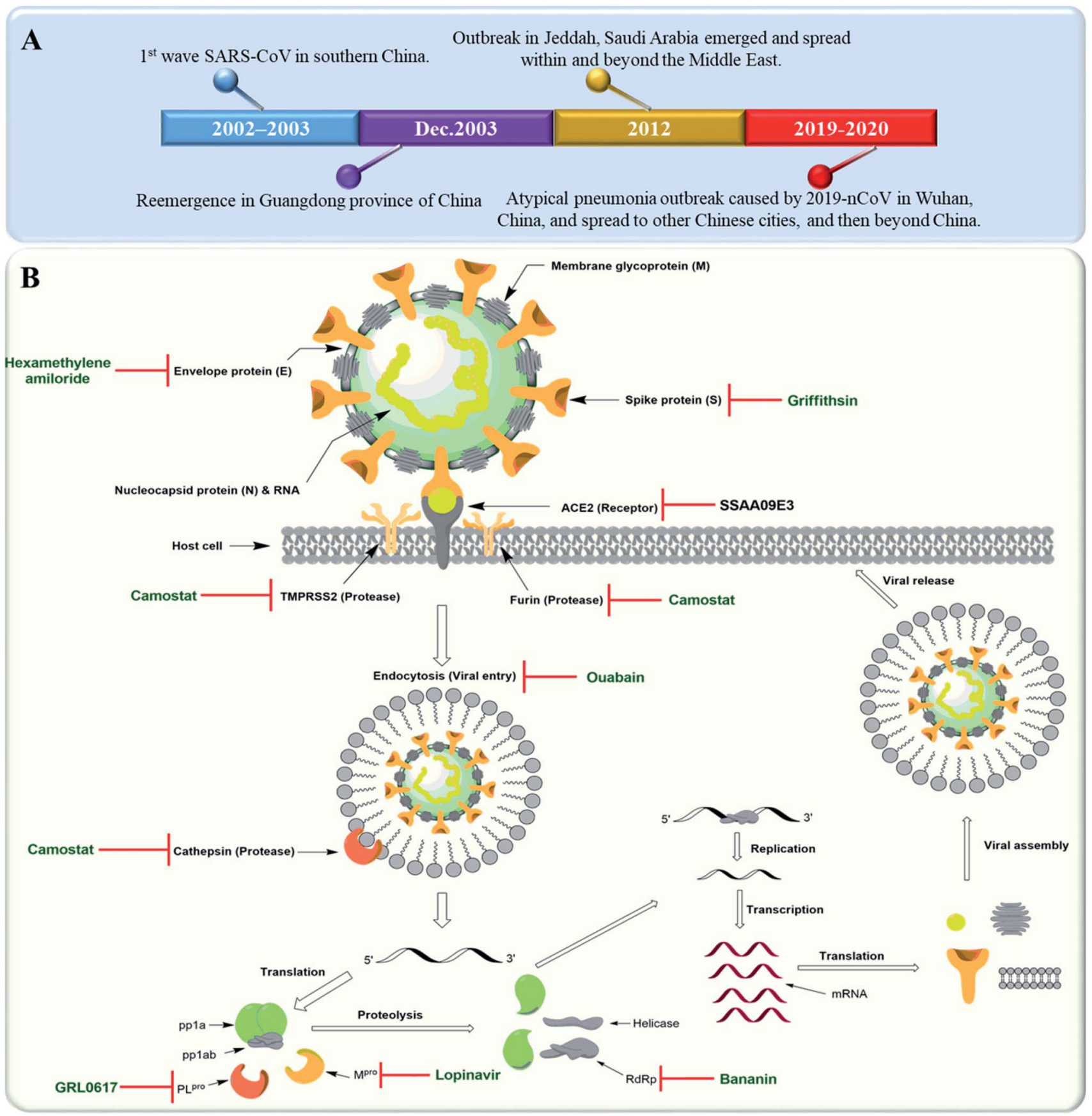

Fig. 1 (A) Timeline of SARS-CoV outbreaks during the last two decades. (B) Coronavirus structure and its life cycle, illustrating the main molecular targets and their inhibitors.

products against SARS-CoV". Cross-referencing and "related articles" functions were used to expand the search criteria. Searches were further supplemented with publicly available information and reports from US Centers for Disease Control and Prevention and WHO websites. Furthermore, we carried out an in silico exploration of a library of phenolic natural products (496 compounds) via a computer-aided virtual screening against the active site of the SARS-CoV Main protease $\left(\mathrm{M}^{\mathrm{pro}}\right)$ and a drug-likeness computation of the compounds reported in this review (75 compounds).

\section{Anti-SARS CoV therapeutic drugs}

\subsection{Virus-based targets and their therapeutics}

Many plant derived therapeutics exhibited an in vitro efficacy against multiple SARS viral targets viz. viral entry into host cells, viral processing (viral protease), viral replication (transcription and translation), and viral release from infected cells (Fig. 1B).

SARS-CoV replicase gene has been revealed to encode a number of enzymatic functions. ${ }^{5}$ These include $\mathrm{M}^{\text {pro }}$ (nsp5), a papain-like protease ( $\mathrm{PL}^{\mathrm{pro}}, \mathrm{nsp} 3$ ), an RNA-dependent RNA 


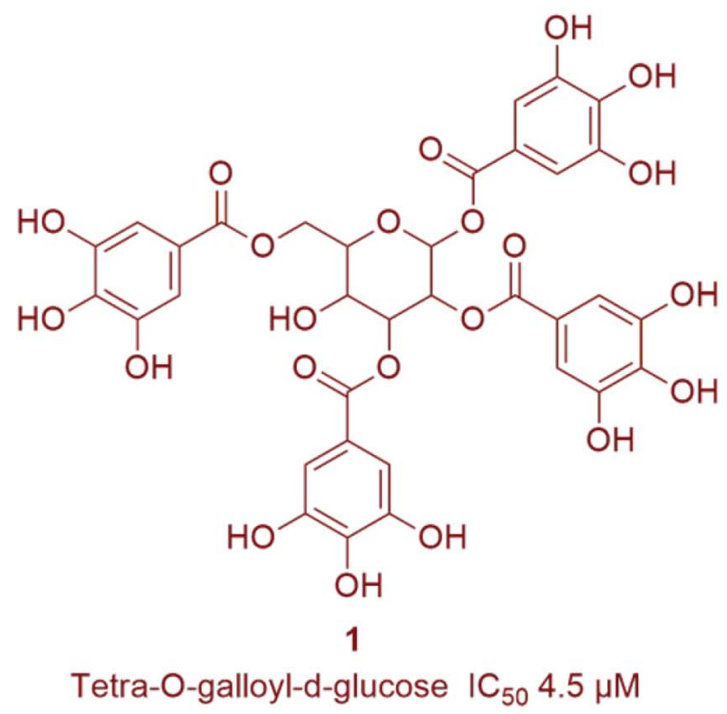<smiles>Cc1cc(O)c2c(c1)C(=O)c1cc(O)cc(O)c1C2=O</smiles>

2

Emodin $\mathrm{IC}_{50} 1 \mu \mathrm{M}$<smiles>O=C(O)c1cc(O)c2c(c1)C(=O)c1cccc(O)c1C2=O</smiles>

3<smiles>O=C(Nc1ccc2c(c1)C(=O)c1ccccc1C2=O)c1ccccc1</smiles>

Synthetic anthraquinone derivative (SSAA09E3) $\mathrm{IC}_{50} 9.7 \mu \mathrm{M}$

Fig. 2 Representative natural products with SARS CoV S-protein-ACE-II binding inhibitory action (in vitro) viz. anthraquinones (blue) and tannins (brown).

polymerase (RdRp, nsp12), and a helicase (HEL1, nsp13). Such essential functional proteins have been selected as potential targets for the development of new anti-SARS CoV therapeutics during the last two decades. Both viral $\mathrm{M}^{\mathrm{pro}}$ and $\mathrm{PL}^{\text {pro }}$ cleave two large replicase polyproteins, viz. pp1a and pp1ab, that are encoded by the open reading frame $1 \mathrm{a} / \mathrm{b}(\mathrm{ORF} 1 \mathrm{a} / \mathrm{b})$ to produce a number of non-structural proteins (nsp 1-15) such as RNAdependent RNA polymerases (RdRp) and helicases that initiate the viral replication process. Such proteases can be considered key factors in the viral life cycle. ${ }^{6}$ Accordingly, their in vitro and in vivo inhibition has exhibited anti-SARS CoV potential (Fig. 1B).

Several small molecules inhibitors for these two enzymes have been reported since 2002 (outlined in Fig. 1B), of which both lopinavir and ritonavir showed a broad spectrum in vitro $\mathrm{M}^{\text {pro }}$ inhibitory activity ${ }^{7}$ as well as clinical efficacy in patients infected by COVID-19. ${ }^{8}$ Similarly, a number of specific and selective inhibitors have been developed against $\mathrm{PL}^{\text {pro }}$, and two of them with a common naphthalene benzamide scaffold are under clinical trials now. ${ }^{9,10}$ Broad-spectrum RdRp and helicase inhibitors like ribavirin and bananin, respectively have shown some clinical efficacy against SARS-CoV and MERS-CoV. ${ }^{11,12}$ The $\mathrm{CoV}$ small hydrophobic envelope protein (E-protein) was found to contain cation-selective ion channels similar to the mouse hepatitis virus (MHV) and human immunodeficiency virus (HIV). Inhibitors for such ion channels like hexamethylene amiloride have a well-proven in vitro and in vivo anti-CoV efficacy ${ }^{13}$

\subsection{Host-based targets and their therapeutics}

ACE-II enzyme was found to be a functional and specific receptor for the viral spike-glycoproteins (S-protein). Hence, its antibodies were able to interfere with the viral entry to the host cells, and thus blocking viral replication. ${ }^{14}$ The spike glycoproteins (S1 and S2 subunits) were also reported to be potential targets for neutralizing antibodies and oligosaccharide-specific binding proteins (e.g. Griffithsin, a natural product derived from the red algae Griffithsia), in addition to several small molecules fusion inhibitors ( $\mathrm{S} 2$ subunit inhibitors). ${ }^{15}$ Other host proteases that could be targeted for drug development include the endosomal cysteine protease i.e. cathepsins that facilitate endosomal cell entry of $\mathrm{CoV},{ }^{16}$ and both the transmembrane protease serine 2 (TMPRSS2) and furin, that cleave and activate spike proteins into the $\mathrm{S} 1$ and S2 subunits to mediate the non-endosomal virus entry at the plasma membrane. ${ }^{17}$ The broad-spectrum serine protease inhibitor camostat possessed in vitro inhibitory activity toward cathepsins, furin and TMPRSS2 and significant in vivo efficacy. Moreover, viral entry via endocytosis was also found to be inhibited by cardiotonic steroids such as ouabain and bufalin at nanomolar concentrations ${ }^{18}$ (Fig. 1B).

\section{Anti-SARS CoV natural therapeutics}

\subsection{Viral entry inhibitors}

Natural therapeutic agents that target viral entry are considered an important class of antiviral therapeutics because of their potential to block the first step of viral infection and hence, preventing its propagation and ability to evolve and acquire drug resistance. SARS-CoV virus entry is initiated when the spike glycoprotein (S) efficiently bind with a metallopeptidase, ACE-II on host cell. ${ }^{19}$

3.1.1. S-protein-ACE-II binding inhibitors. Several natural products that target CoV S-protein to prevent its binding with ACE-II, have been reported. In 2004, a group of Chinese 
<smiles>CC(C)(C)O[Mg]</smiles><smiles>CCOC(=O)c1cc(=O)oc2cc(O)c(O)cc12</smiles><smiles>O=C(OC[C@H]1O[C@@H](OC(=O)c2cc(O)c(O)c(O)c2)[C@H](OC(=O)c2cc(O)c(O)c(O)c2)[C@H](OC(=O)c2cc(O)c(O)c(O)c2)[C@@H]1OC(=O)c1cc(O)c(O)c(O)c1)c1cc(O)c(O)c(O)c1</smiles><smiles></smiles>

Esculetin-4-carboxylic acid ethyl ester $\mathrm{IC}_{50} 46 \mu \mathrm{M}$

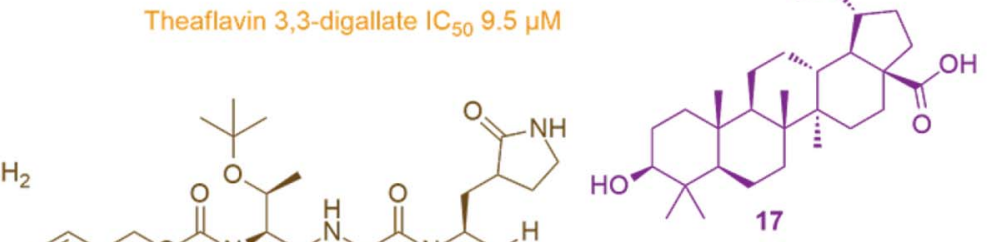<smiles>CC(C)[C@H](NC(=O)c1ccc(O)cc1)C(=O)N[C@H](C(=O)N[C@@H](CCCNC(=N)N)C(=O)[SiH3])C(C)C</smiles>

Synthetic $\mathrm{M}^{\mathrm{Pro}}$ inhibitor inspired by Tokaramide

TG-020522: $I_{50} 0.6 \mu \mathrm{M}$<smiles>c1ccc2c(c1)CCCCCCCOC2</smiles><smiles>CNCC(N)=O</smiles>

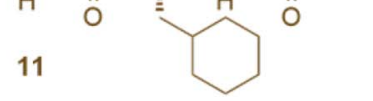
Betulinic acid $I C_{50} 8.2 \mu \mathrm{M}$

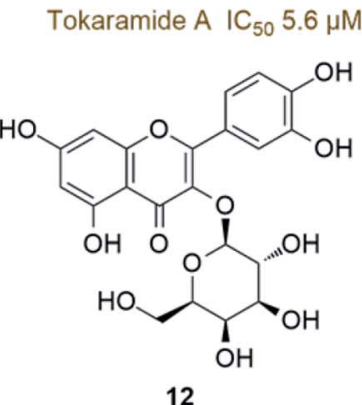

Hyperoside $\mathrm{IC}_{50} 42.8 \mu \mathrm{M}$<smiles>O=c1cc(-c2ccc(O)c(O)c2)oc2cc(O)cc(O)c12</smiles>

13<smiles>O=C1CC(Cc2ccccc2)Oc2ccc(Cc3cccc(Cl)c3)c(O)c21</smiles>

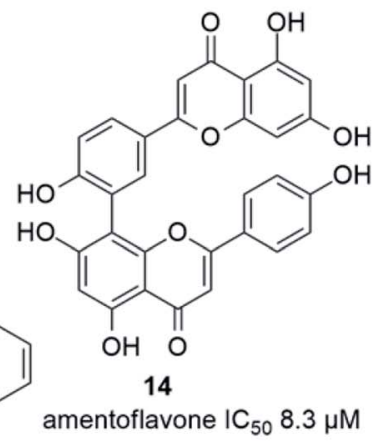<smiles>CCc1ccc2c(c1)OCO2</smiles>

15

Synthetic Mpro inhibitor inspired by flavonoid scaffold $\mathrm{IC}_{50} 4 \mu \mathrm{M}$

Fig. 3 Representative natural products with SARS CoV $M^{\text {pro }}$ in vitro inhibitory action viz. alkaloids (blue), coumarins (red), tannins (orange), peptides (brown), terpenes (purple) and flavonoids (black).

researchers screened their traditional herbal medicine (Traditional Chinese Medicine, TCM) for potential natural products that can bind with S-protein. Their extensive virtual screening followed by in vitro validation enabled them to identify a number of phenolic compounds, among which tetra- $O$-galloyl$\beta$-D-glucose (1) (Fig. 2) was reported as a potent S-protein-ACE-II binding inhibitor $\left(\mathrm{IC}_{50} 4.5 \mu \mathrm{M}\right){ }^{20}{ }^{20}$ Three years later, another Chinese research group screened a large number of medicinal plants belonging to Polygonaceae family, i.e. Rheum officinale and Polygonum multiflorum, for the possible discovery of antiCoV natural therapeutics. They found that emodin (2) and its related anthraquinone derivative, i.e. rhein (3) significantly blocked the ACE-II and S-protein interaction in a dosedependent manner with $\mathrm{IC}_{50}$ of 1-10 $\mu \mathrm{M}$ (Fig. 2). ${ }^{21}$ Thereafter, this class of compounds inspired the synthesis of an anthraquinone-based derivative such as SSAA09E3 (4) (IC IC $_{50} 9.7$ $\mu \mathrm{M})$ (Fig. 2) which exhibited interesting pharmacodynamic and pharmacokinetic properties and hence, it was selected to be 


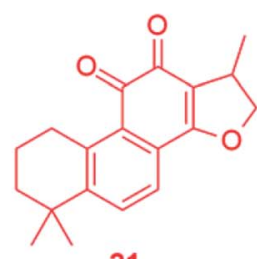

21

Tanshinone derivative $\mathrm{IC}_{50} 0.8 \mu \mathrm{M}$<smiles>O=C1c2ccccc2-n2c1nc1ccccc1c2=O</smiles>

Tryptanthrin $\mathrm{IC}_{50} 1.52 \mu \mathrm{M}$<smiles>CC(C)=CCc1cc2c(cc1O)oc(=O)c1c3ccc(O)cc3oc21</smiles>
26 Psoralidin $\mathrm{IC}_{50} 4.2 \mu \mathrm{M}$<smiles>O=C(/C=C/CCc1ccc(O)c(O)c1)CCc1ccc(O)c(O)c1</smiles>

22<smiles>CC(C)=CCc1c(O)ccc(C(=O)/C=C/c2ccc(O)cc2)c1O</smiles>

23

Isobavachalcone $\mathrm{IC}_{50} 7.3 \mu \mathrm{M}$,

Hirsutenone $I_{50} 4.1 \mu \mathrm{M}$<smiles>CC(C)=CCc1cc(C(=O)/C=C/c2ccc(O)c(O)c2)c(O)cc1O</smiles>

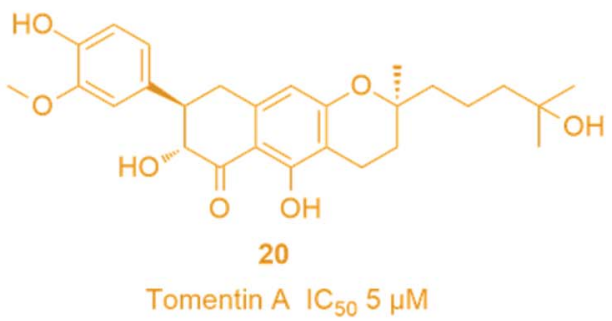

Chalcone derivative Mpro IC ${ }_{50} 27.9 \mu \mathrm{M}$, PLpro IC $_{50} 112.9 \mu \mathrm{M}$<smiles>O=c1c(O[C@@H]2O[C@H](CO)[C@@H](O)[C@H]2O)c(-c2ccc(O)cc2)oc2cc(O)cc(O)c12</smiles><smiles>CCCCc1cc(-c2oc3cc(O)c(CC=C(C)C)c(O)c3c(=O)c2O)cc(O)c1O</smiles>

Papyriflavonol A $\quad I_{50}$ value of $3.7 \mu \mathrm{M}$<smiles>C[C@@H]1O[C@H](Oc2c(-c3ccc(O)cc3)oc3cc(O)cc(O)c3c2=O)[C@H](O)[C@@H](O)[C@H]1O</smiles>

Fig. 4 Representative natural products with SARS CoV PL ${ }^{\text {pro }}$ in vitro inhibitory action viz. chalcones (blue), terpenes (Red), flavonoids (orange), alkaloids (brown), coumarins (purple), and viral release inhibitors viz. flavonoid glycosides (black).

further subjected for preclinical evaluation as a CoV entry inhibitor. $^{22}$

\subsection{Inhibitors of viral replication}

Being one of the most prominent molecular targets in COVID$19, \mathrm{M}^{\mathrm{pro}}$ and $\mathrm{PL}^{\text {pro }}$ inhibitors were selected for the development of potential anti-SARS CoV therapeutics. Several small molecules have been developed during and after the first and second CoV spread waves. Among which, many edible plantsderived natural products and their related synthetic derivatives have offered a number of interesting potential inhibitors with well-proven safety and efficacy.

3.2.1. $\mathbf{M}^{\text {pro }}$ inhibitors. Isatis indigotica was one of the first medicinal plants that have been reported to possess anti-SARS $\mathrm{CoV}$ potential. A deeper investigation into its metabolites that could be attributable to the observed antiviral action led to the characterization of several isatin-derived alkaloids indican (5) and indigo (6) (Fig. 3) and other phenolic compounds with $\mathrm{M}^{\text {pro }}$ in vitro inhibitory action. ${ }^{23} \mathrm{~A}$ year later, the isatin scaffold was utilized for developing more potent semi-synthetic derivative (7) that possessed $\mathrm{M}^{\text {pro }}$ inhibitory action at nanomolar concentrations with $\mathrm{IC}_{50}$ of $0.37 \mu \mathrm{M}$ (Fig. 3). ${ }^{24}$

The rapid development of computer-aided drug design (CADD) used for the in silico molecular modelling along with the growing small molecules libraries derived by the aid of combinatorial chemistry have dramatically improved the drug discovery and development process. During the last coronavirus waves, such computer-based approaches have contributed to finding a wide array of new and potent drug leads. Natural product libraries and databases have also been utilized to find 
A

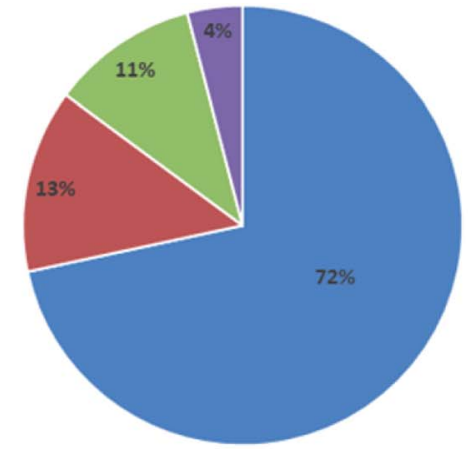

- Phenolics | Tepenes || Alkaloids | Peptides
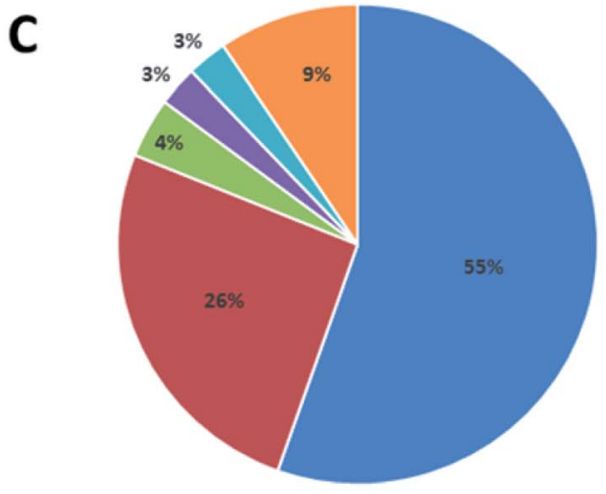

n Mpro

- PLpro = ACE2-S

n Cathepsin

nelicase

m Unknown

B

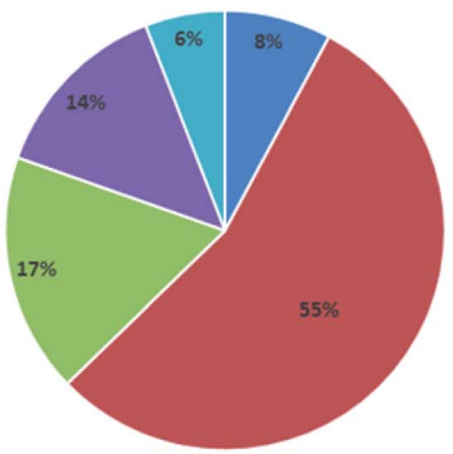

ETannins || Flavonoids $\mid$ Chalcones | Cinnamic acid derivatives $\mid$ Anthraquinones

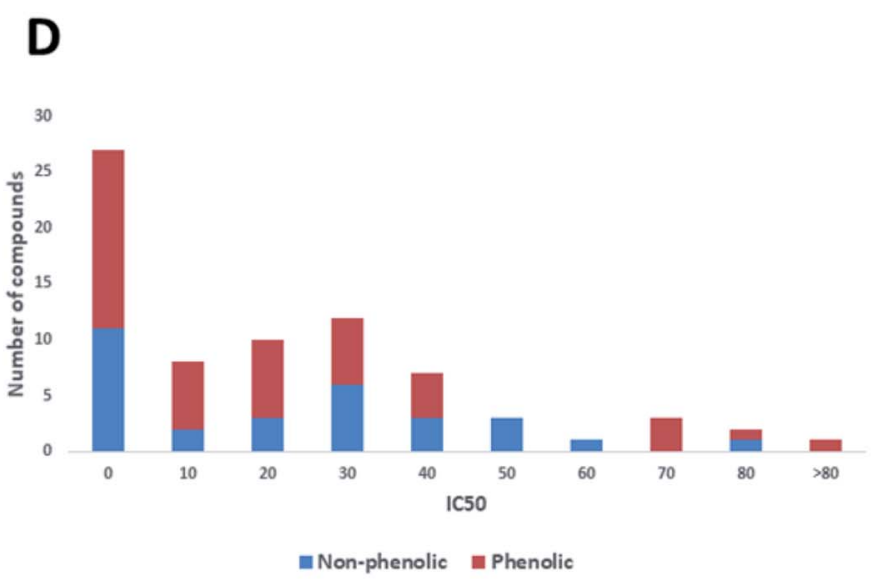

Fig. 5 Pie charts indicating the reported anti-SARS CoV natural therapeutic classes (A \& B), and their common viral targets (C). A bar chart depicting activity range of the reported natural products illustrating phenolic compounds as being the most prominent class of compounds (D).

potential anti-SARS CoV therapeutics. In 2004, shortly after the first SARS-CoV spread, a number of polyphenolic metabolites of which tannic acid (8), and theaflavin-3,3'-digallate (9) (Fig. 3) were reported as potent viral $\mathrm{M}^{\text {pro }}$ inhibitors $\left(\mathrm{IC}_{50} 3\right.$ and $9.5 \mu \mathrm{M}$, respectively). These compounds were filtered out from a library of phenolic compounds consisted of 720 compounds using an in silico approach called structure-based virtual screening. ${ }^{25}$

Later on, a number of natural peptides i.e. tokaramide A (10) (Fig. 3) derived from the marine organism Theonella mirabilis $^{26,27}$ inspired another research group to develop a semisynthetic peptide derivative i.e. TG-0205221 (11) with a nanomolar $\mathrm{M}^{\text {pro }}$ inhibition activity $\left(\mathrm{IC}_{50} 0.6 \mu \mathrm{M}\right)$, where they exhibited a non-competitive inhibition through the formation of covalent bonds with their binding sites (Fig. 3). ${ }^{28}$ Following the screening of natural product databases, another research group reported for hyperoside (quercetin-3- $\beta$-galactoside) (12) as being a promising $\mathrm{M}^{\text {pro }}$ inhibitor with $\mathrm{IC}_{50}$ of $42.79 \mu \mathrm{M}$. They also studied the structure-activity relationship of this flavonoid in comparison with a number of related derivatives and found that a hydroxyl group at C- $3^{\prime}$ is an essential structural requirement for hyperoside competitive inhibitory action (Fig. 3). ${ }^{29}$

As part of the ongoing investigation of flavonoids-based antiviral candidates, Ryu and co-workers in 2010, reported the
$\mathrm{M}^{\text {pro }}$ inhibitory activity $\left(\mathrm{IC}_{50} 20-200 \mu \mathrm{M}\right)$ of some common flavonoids i.e. quercetin, apigenin and luteolin (13) and bioflavonoids such as amentoflavone (14), with the latter possessing better in vitro inhibitory activity $\left(\mathrm{IC}_{50} 8.3 \mu \mathrm{M}\right)$. These findings revealed that larger polyhydroxylated compounds are more preferred to develop potent $\mathbf{M}^{\text {pro }}$ noncompetitive inhibitors (Fig. 3). ${ }^{30}$ Such interesting activity together with the simplicity of flavonoids-based inhibitors encouraged another researcher group to develop potent inhibitors analogs such as compound (15) based on the flavonoids scaffold which were subjected for a preclinical trial (Fig. 3). ${ }^{31}$ In 2013, eight phlorotannins, isolated from an edible brown algae Ecklonia cava, namely eckol (16), dieckol, triphloretol A, dioxinodehydroeckol, 2-phloroeckol, 7-phloroeckol, fucodiphloroethol G and phlorofucofuroeckol A, with the first two compounds (Fig. 3) possessing the most potent SARS-CoV $\mathrm{M}^{\text {pro }}$ inhibitory activities $\left(\mathrm{IC}_{50} 8.8\right.$ and $2.7 \mu \mathrm{M}$, respectively). ${ }^{32}$ Epigallocatechin gallate and gallocatechin gallate showed good $\mathrm{M}^{\text {pro }}$ inhibition activity ( $\mathrm{IC}_{50} 73$ and $47 \mu \mathrm{M}$, respectively) with their galloyl moiety at 3$\mathrm{OH}$ position required for the antiviral action. ${ }^{33}$

Herbacetin, rhoifolin and pectolinarin showed anti-SARSCoV $\mathrm{M}^{\text {pro }}$ action ( $\mathrm{IC}_{50} 33.17,27.45$ and $37.78 \mu \mathrm{M}$, respectively) using a tryptophan-based fluorescence method. ${ }^{34}$ 
A

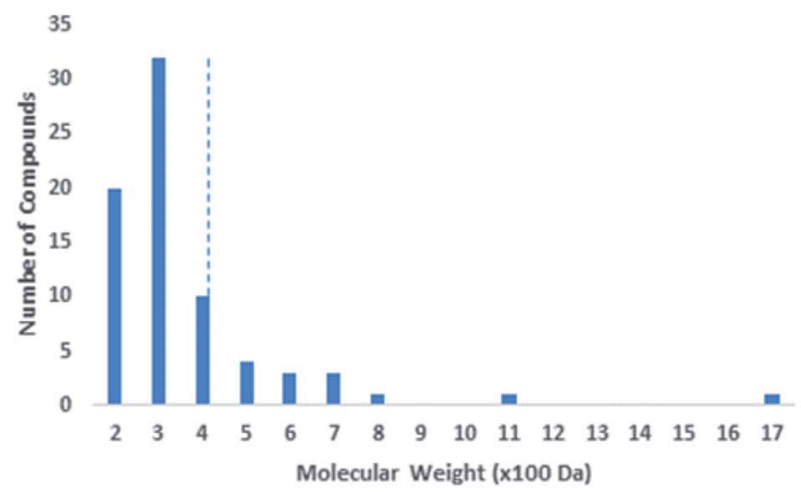

C

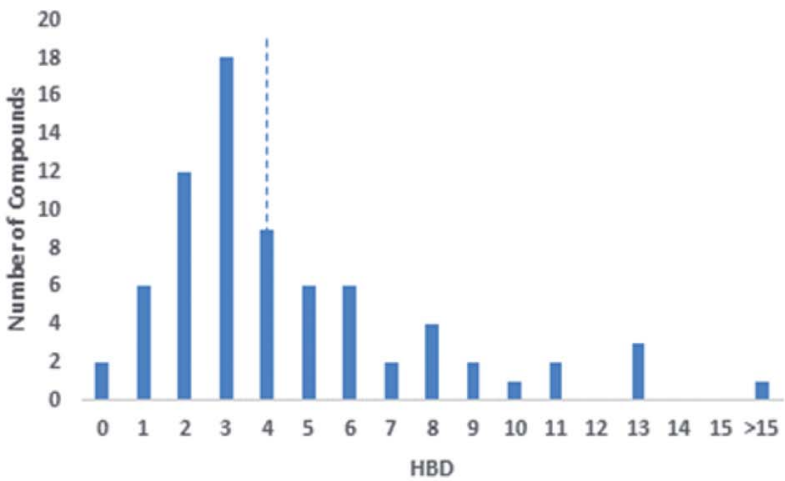

E

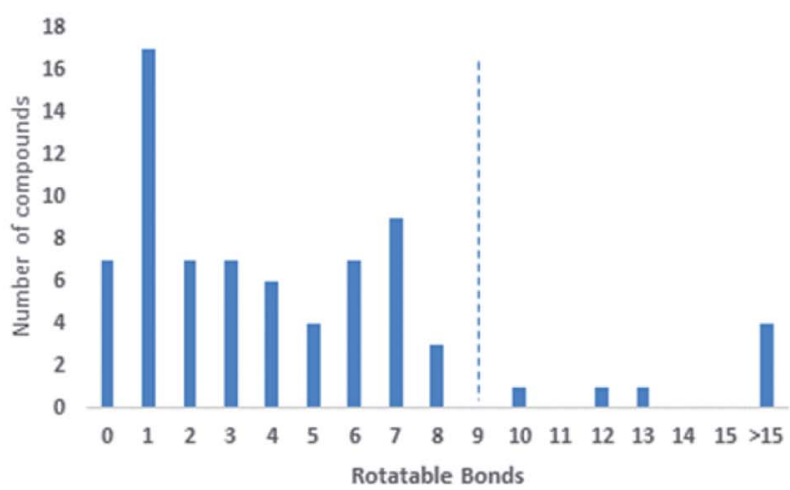

B

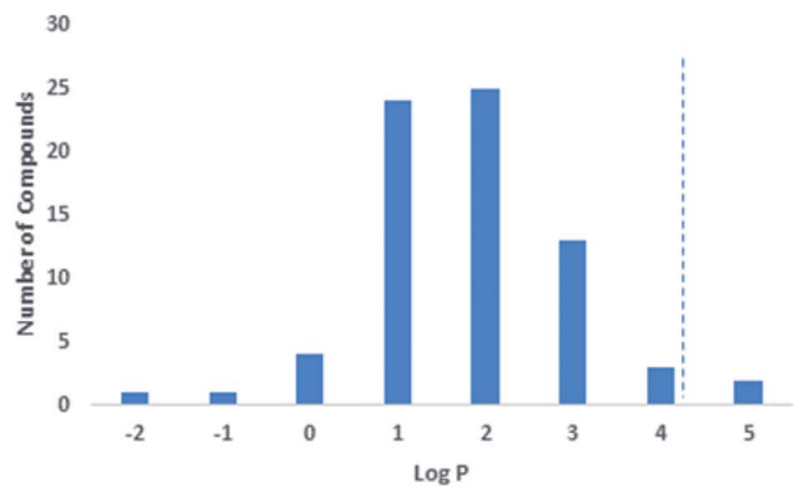

D

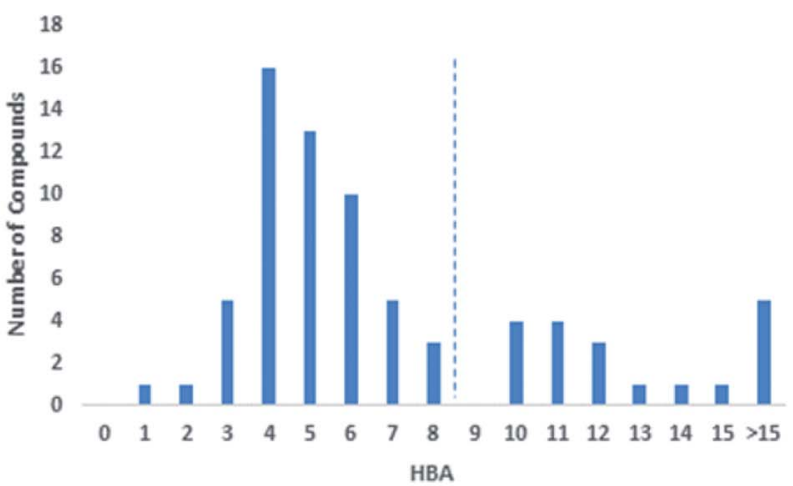

$\mathbf{F}$

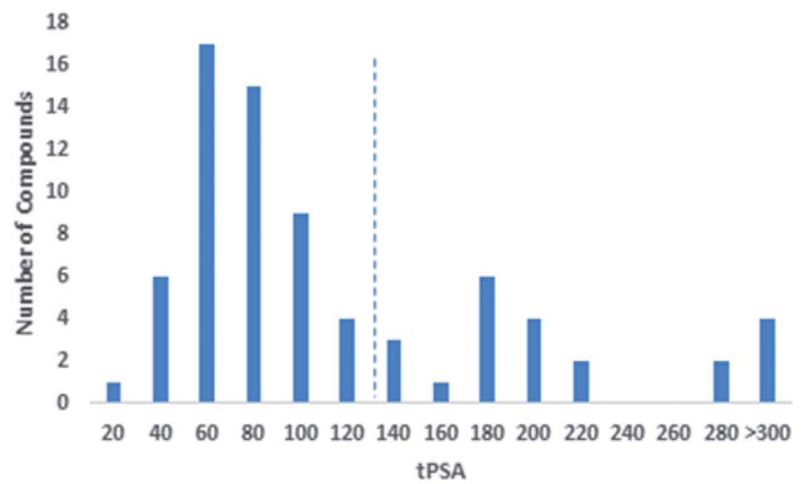

Fig. 6 Analysis of the physicochemical properties of anti-SARS CoV natural products displayed in terms of molecular weight (A), calculated log $P$ $(B), H B D(C), H B A(D)$, number of rotatable bonds (E), and tPSA (F).

Scutellarein, myricetin, quercetagetin, and robinetin were reported in a Chinese patent to inhibit SARS $\mathrm{M}^{\text {pro }}$ activity in a fluorescent assay. ${ }^{2}$ The former two compounds also were proved to inhibit the SARS-CoV helicase protein in vitro by affecting the ATPase activity. ${ }^{35}$ High throughput screening of natural product libraries led to the discovery of two interesting $\mathrm{M}^{\text {pro }}$ competitive inhibitors i.e. betulinic acid (17) and savinin (18) $\left(\mathrm{IC}_{50} 8.2\right.$ and $9.1 \mu \mathrm{M}$, respectively). Both compounds were able to bind the enzyme's active site constituting S1 and S2 subsites via multiple hydrogen bonds with Asn 142, Gln 189 and
Cys 145 amino acid residues. Thus, they could be promising starting points for developing more potent derivatives, particularly, betulinic acid (17) (Fig. 3) which is abundant in many edible and medicinal plants. ${ }^{36}$

Four quinone-methide triterpenes were reported to exhibit $\mathrm{M}^{\text {pro }}$ inhibitory actions namely celastrol, pristimerin, tingenone and iguesterin $\left(\mathrm{IC}_{50} 10.3,5.5,9.9\right.$, and $2.6 \mu \mathrm{M}$, respectively), which were isolated from the bark of Tripterygium regelii (F. Celastraceae), a woody vine used in traditional Chinese 
A

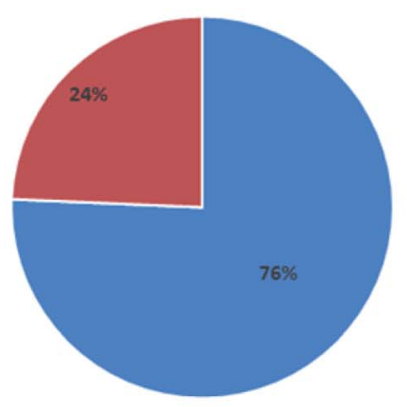

- Have drug-like properties = Haven't drug-like properties

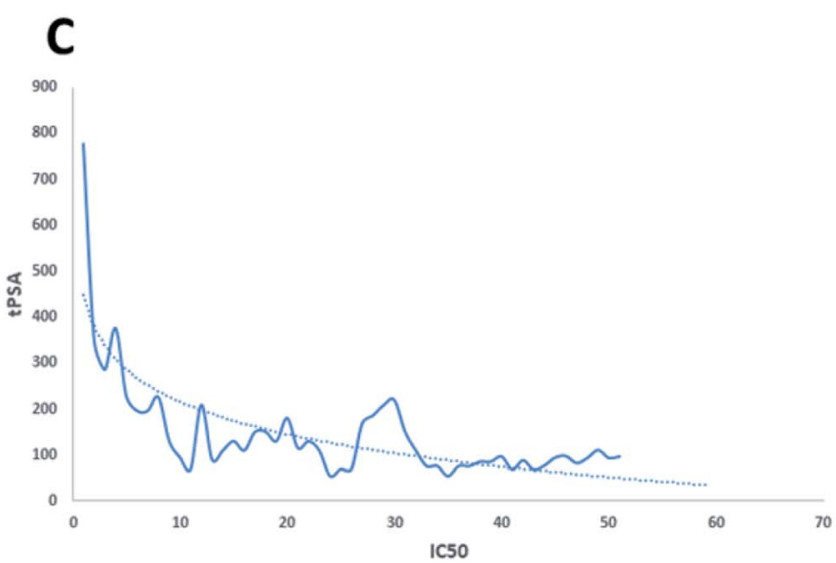

B

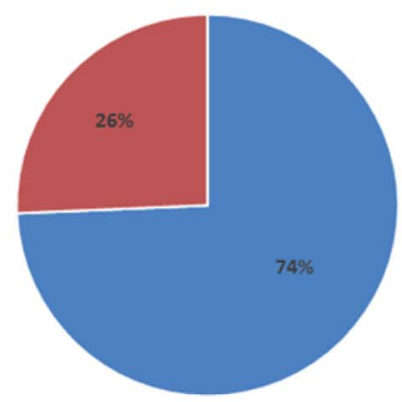

" Favourable oral bioavailability = Unfavourable oral bioavailability

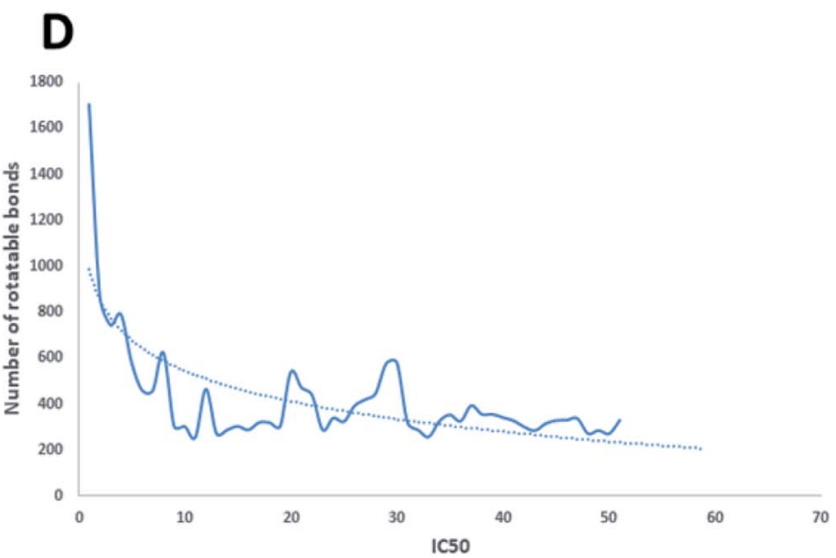

\section{E}

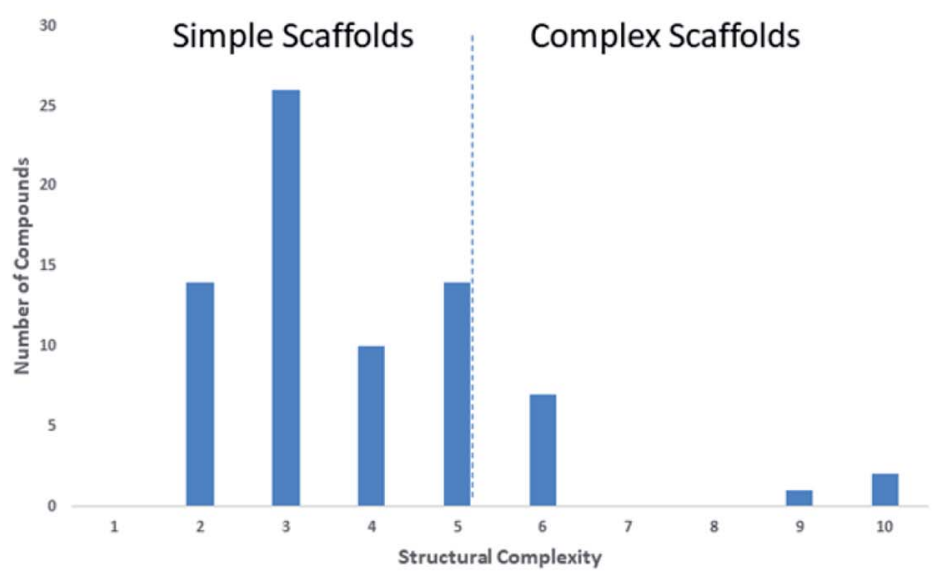

Fig. 7 The compliance of the tested natural products with drug-likeness rules Lipinski's and Veber's rules (A \& B, respectively). The relationship between the $I_{50}$ and both tPSA and the number of rotatable bond (C \& D, respectively). Distribution of the reported anti-SARS CoV natural products depending on their scaffold's complexity (E).

medicine in the treatment of inflammatory and autoimmune diseases. ${ }^{37}$

A coumarin compound named esculetin-4-carboxylic acid ethyl ester (19) (Fig. 3), isolated from tropical marine sponge Axinella corrugata, was reported to possess $\mathrm{M}^{\text {pro }}$ inhibitory action with $\mathrm{IC}_{50}$ value of $46 \mu \mathrm{M} .^{38}$ Isolinoleic acid (at a concentration of $50 \mu \mathrm{M})$ possessed $\mathrm{M}^{\text {pro }}$ inhibitory potential as reported in another Chinese patency. ${ }^{2}$
3.2.2. $\mathbf{P L}^{\text {pro }}$ inhibitors. In vitro activity against $\mathrm{CoV} \mathrm{PL}^{\text {pro }}$ was reported by a number of natural products such as geranylated flavonoids (Fig. 4), i.e. tomentin A (20), tomentin B, tomentin C, tomentin D, tomentin E, $3^{\prime}-O$-methyldiplacol, $4^{\prime}-O-$ methyldiplacol, $3^{\prime}$-O-methyldiplacone, 4'-O-methyldiplacone, mimulone, diplacone, and 6-geranyl-4' ${ }^{\prime}, 5,7$-trihydroxy-3' ${ }^{\prime}, 5^{\prime}$ dimethoxyflavanone, isolated from Paulownia tomentosa fruits. ${ }^{39}$ Tanshinones isolated from Salvia miltiorrhiza, ${ }^{40}$ and 


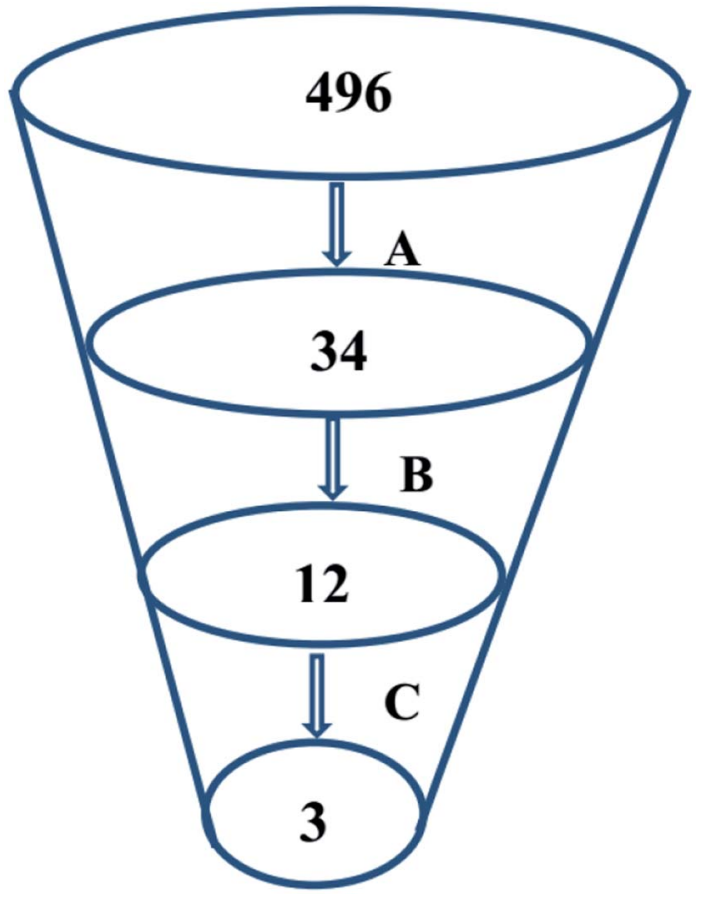

Fig. 8 An outline of the employed virtual screening methodology that comprised of (A) phenolic compounds library virtual screening via molecular docking, (B) selection of the docking poses maintaining the essential binding interactions and (C) selection of top phenolic hits with the most acceptable drug-likeness properties.

diarylheptanoid hirsutenone derived from the stem bark of Alnus japonica. ${ }^{41}$ Park and co-workers identified a number of tanshinone derivatives as being potent $\mathrm{PL}^{\text {pro }}$ inhibitors. One of them (21) was found to be the most potent noncompetitive inhibitor $\left(\mathrm{IC}_{50} 0.8 \mu \mathrm{M}\right)$, that was able to bind to the enzyme's active site covalently. In parallel work, the same research group characterized a diarylheptanoid derivative hirsutenone (22) with an $\alpha, \beta$-unsaturated carbonyl group that was also able to form a covalent bond with a cysteine residue (Cys-145) in the enzyme's active site leading to a significant in vitro inhibition ( $\left.\mathrm{IC}_{50} 4.1 \mu \mathrm{M}\right)$. They also reported a novel geranylated flavonoid derivative with a dihydro- $2 H$-pyran moiety with promising inhibitory activity ( $\mathrm{IC}_{50}$ value of $\left.5 \mu \mathrm{M}\right){ }^{42}$

Recently, Park and his co-workers identified several polyhydroxylated chalcone derivatives, i.e. isobavachalcone (23), 4hydroxyderricin, xanthoangelol, xanthoangelol $\mathrm{F}$, xanthoangelol D, xanthoangelol E, xanthoangelol B, xanthoangelol $\mathrm{G}$ and xanthokeistal A, and coumarins from Angelica keiskei, i.e. psoralen, bergapten, xanthotoxin and isopimpinellin (Fig. 4), as being potent competitive inhibitors of both $\mathrm{M}^{\text {pro }}$ and $\mathrm{PL}^{\text {pro }}$ with $\mathrm{IC}_{50}$ values ranging from 5.8 to $11.9 \mu \mathrm{M}$. Xanthoangelol E, containing the perhydroxyl group, exhibited the most potent $\mathrm{M}^{\text {pro }}$ and $\mathrm{PL}^{\text {pro }}$ inhibitory activity with $\mathrm{IC}_{50}$ values of 11.4 and $1.2 \mu \mathrm{M}$, respectively. ${ }^{43}$ Another group of polyphenolic compounds, were isolated from the medicinal plant Broussonetia papyrifera, of which a chalconoid derivative (24) showed the best inhibitory potential against both $\mathrm{M}^{\text {pro }}$ and $\mathrm{PL}^{\text {pro }}\left(\mathrm{IC}_{50}\right.$ 27.9 and $112.9 \mu \mathrm{M}$, respectively). ${ }^{44}$ Tryptanthrin (25) isolated from Strobilanthes cusia leaf inhibited the cleavage activity of $\mathrm{PL}^{\mathrm{pro}}$ and the post-entry stage of viral replication with $\mathrm{IC}_{50}$ of $1.52 \mu \mathrm{M} .{ }^{45}$ Six cinnamic amides i.e. $N$-trans-caffeoyltyramine, $N$ trans-coumaroyltyramine, $N$-trans-feruloyltyramine, terrestriamide and $\mathrm{N}$-trans-feruloyloctopamine, isolated from Tribulus terrestris fruits, showed significant $\mathrm{PL}^{\text {pro }}$ inhibition $\left(\mathrm{IC}_{50}\right.$ values ranging from 15.8 to $70.1 \mu \mathrm{M})$. The latter compound possessed the most potent inhibition with $\mathrm{IC}_{50}$ of $15.8 \mu \mathrm{M} .{ }^{46}$ Six phenolic compounds with good $\mathrm{PL}^{\text {pro }}$ inhibitory actions $\left(\mathrm{IC}_{50}\right.$ ranging between 4.2 and $38.4 \mu \mathrm{M}$ ), namely bavachinin, neobavaisoflavone, 4'-O-methylbavachalcone, corylifol A, isobavachalcone and psoralidin (26) were isolated from Psoralea corylifolia seeds. The latter two compounds showed the most potent actions with $\mathrm{IC}_{50}$ values of 7.3 and $4.2 \mu \mathrm{M}$, respectively. ${ }^{47}$ The inhibitory potential of ten polyphenols derived from Broussonetia papyrifera roots, i.e. broussochalcone A, broussochalcone B, 4-hydroxyisolonchocarpin, papyriflavonol A (27), 3'(3-methylbut-2-enyl)-3',4,7-trihydroxyflavane, kazinol A, kazinol $\mathrm{B}$, broussoflavan $\mathrm{A}$, kazinol $\mathrm{F}$ and kazinol J, were tested against the two SARS CoV proteases with a more potent inhibition recorded against $\mathrm{PL}_{\mathrm{pro}}$ than that of $3 \mathrm{CL}^{\text {pro }}$. The most potent $\mathrm{PL}^{\mathrm{pro}}$ inhibition was exhibited by the prenylated flavone derivative viz. papyriflavonol A (27) with $\mathrm{IC}_{50}$ value of $3.7 \mu \mathrm{M}$, exceeding the inhibitory potential of non-prenylated flavone derivatives viz. quercetin and kaempferol $\left(\mathrm{IC}_{50} 8.6\right.$ and $16.3 \mu \mathrm{M}$, respectively). This signified the crucial role of the prenyl group in forming stronger hydrophobic interactions with the enzyme as well as the increase in the hydroxylation in the flavone backbone. $^{48}$

\subsection{Viral release inhibitors}

Several kaempferol derivatives (Fig. 4) were reported to block the 3a channel of Coronavirus, which are formed by the ORF 3acoded proteins, thus counteracting the viral production and release from the host cells. This gives the body a chance to adjust its immune system to counteract the viral attack. Kaempferol glycosides were proved to possess more potent inhibitory effect than kaempferol and this pointed out to the significance of sugar residues for the antiviral activity. Juglanin (kaempferol-3-O- $\alpha$-L-arabinofuranoside) (28) was the most effective glycoside with an $\mathrm{IC}_{50}$ value of $2.3 \mu \mathrm{M}$. Other kaempferol glycosides i.e. tiliroside (kaempferol-3-O-(6-p-coumaroyl)glucoside) (29) and afzelin (kaempferol-3-O- $\alpha$-L-rhamnoside) (30) were less potent than juglanin (28) but showed similar activity to that of emodin (2).49

\section{Analysis of drug-likeness properties}

The druggability of any molecule is determined depending on its pharmacokinetic properties as well as its excellent pharmacodynamics. Calculating the physicochemical properties (e.g. $\log P$ and molecular weight) of a bioactive compound can predict its possible pharmacokinetics (e.g. absorption and bioavailability). Lipinski's rule of five considers a given bioactive compound as a drug candidate if it possess the following 
A

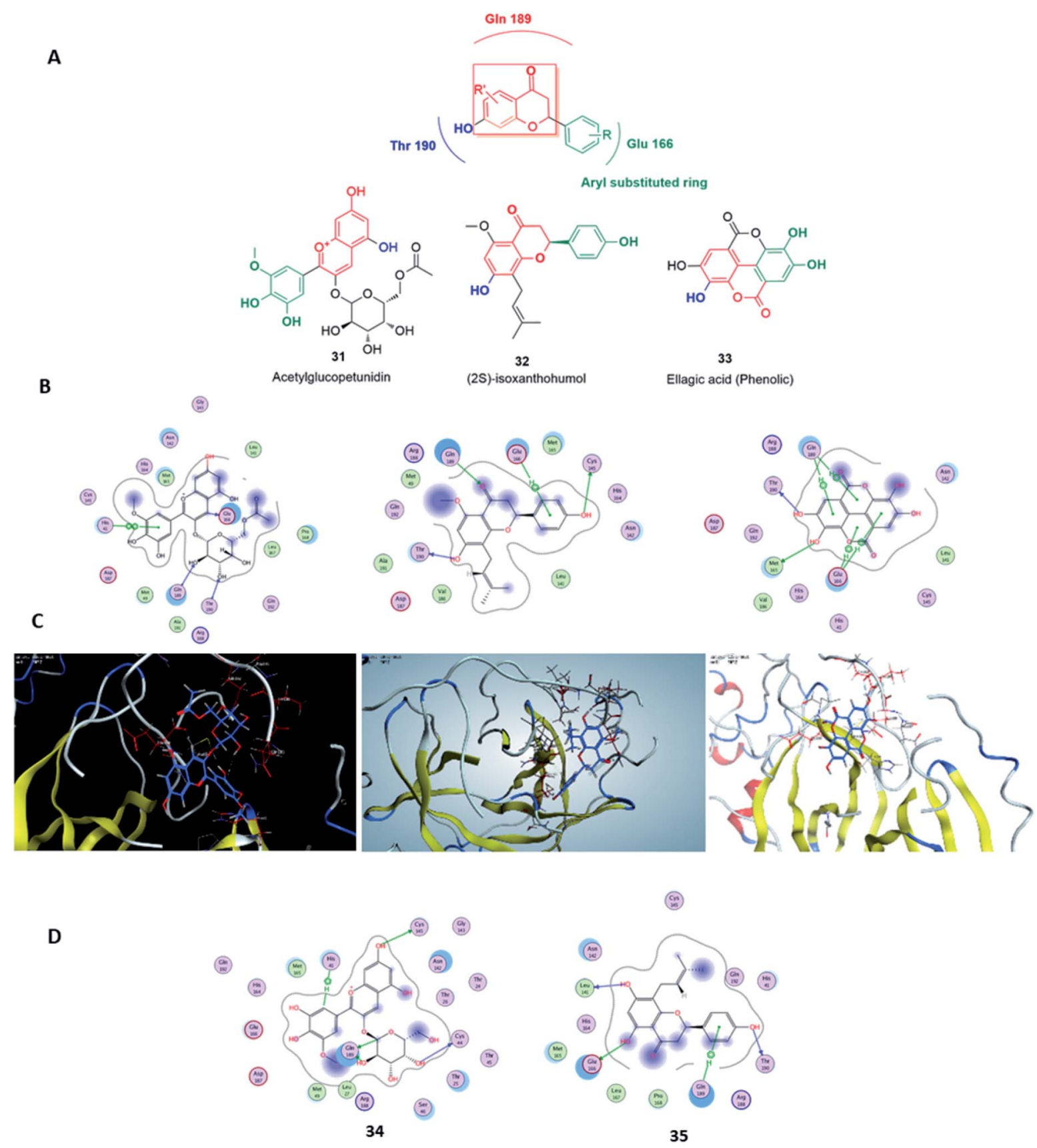

Fig. 9 The main pharmacophore of the top three hits (A), along with their binding modes inside SARS CoV M ${ }^{\text {pro }}$ active sites (B \& C). The binding modes of the hydrolysis metabolites derived from compounds 31 and 32 (D).

physicochemical parameters i.e. $\log P \leq 5$, molecular weight $\leq$ 500 , hydrogen bond donor $[\mathrm{HBD}] \leq 5$, and hydrogen bond acceptor $[\mathrm{HBA}] \leq 10$. Despite, $90 \%$ of orally active drugs that have reached phase 2 clinical status ${ }^{50}$ follow these parameters range, however, meeting the rule of five does not guarantee that a molecule is a drug-like. ${ }^{51}$ Drug's cellular permeability and in turn its distribution and excretion are associated with its topological polar surface area (tPSA) and molecular flexibility (i.e. the number of rotatable bonds). Hence, bioactive molecules with tPSA of $140 \AA$ or less and rotatable bonds of ten or fewer (i.e. Veber's oral bioavailability) can be considered as potential drug candidates. ${ }^{\mathbf{5 1}}$

In this review, the 74 anti-CoV natural products (Table S1, ESI $\dagger$ ) were found to belong to four classes of compounds viz. phenolics, terpenoids, alkaloids and peptides, where phenolics were the most prominent compounds of which flavonoids were the major class (72\%) (Fig. 5). The majority of compounds were found targeting $\mathrm{M}^{\text {pro }}$ and $\mathrm{PL}^{\text {pro }}$ (55\% and $26 \%$, respectively, Fig. 5) indicating that they are the most susceptible targets towards natural products, particularly the phenolics. The antiviral activity of these compounds possessed activity ranging 
from potent to moderate $\left(\mathrm{IC}_{50}\right.$ ranging from 0.0025 to $90 \mu \mathrm{M}$, average $\mathrm{IC}_{50} 20.13 \mu \mathrm{M}$ ), where phenolics were also the most active ones (Fig. 5). The physicochemical characters, viz. molecular weight, $\log P, \mathrm{HBD}, \mathrm{HBA}$, tPSA and rotatable bonds, of the 74 anti-SARS CoV were calculated using LigandScout 4.3 (Vienna, Austria) and projected onto a drug-likeness cut-off. ${ }^{52}$

Regarding the drug-likeness properties, $76 \%$ of the reviewed molecules followed Lipinski's and Veber's rules (Fig. 7), indicating the promising potential of natural products to serve as drug candidates against the newly emerged anti-SARS CoV. The molecular weights of the 74 compounds distributed between 248.24 and 1701.2 Da (average of 138.248 Da), and most of them were between 200 and 400 Da (Fig. 6). Both tannic acid and $\beta$ aescin were the largest molecules. However, they showed potent anti-SARS $\mathrm{CoV}\left(\mathrm{IC}_{50} 3\right.$ and $6 \mu \mathrm{M}$, respectively). The $\log P$ of the compounds under study followed a normal distribution with the major was around 2 , and $79 \%$ of the compounds were of favourable $\log P$ values ( $\leq 5)$ (Fig. 6). Regarding HBD and HBA parameters (average of 3 and 4, respectively, Fig. 6), they showed a distribution pattern similar to that of $\log P$ (Fig. 6) with more than $80 \%$ of compounds were of acceptable numbers. Additionally, $74 \%$ of compounds can demonstrate good oral bioavailability (Fig. 6). Being the most predominant and active compounds, phenolic's tPSA and to some extent of flexibility (number of rotatable bonds) which are interestingly linked to their activity. The compounds with higher tPSA and number of rotatable bonds (i.e. flexible) were found to exhibit higher $\mathrm{IC}_{50}$ values (Fig. 7). Such observation was also found in the peptides class, as they were among the most active compounds $\left(\mathrm{IC}_{50}\right.$ 0.0025 to $6.8 \mu \mathrm{M})$, and also have high tPSA (>140 $)$ and high flexibility (rotatable bonds 12 to 27 ). Natural products are not always available to supply the drug industry due to their limited natural occurrence for some ecological considerations. Accordingly, combinatorial chemistry can aid in providing an alternative source for the natural product itself or its analogs. In this context, we examined the complexity and the synthetic accessibility of our reviewed natural products. As illustrated in Fig. 7, most of the compounds $(>85 \%)$ got a score ranging from 2 to 5 , indicating that they or their analogs could be synthesized if the natural product itself cannot be readily accessible.

\section{In silico analysis of potential anti SARS-CoV 2 agents}

Virtual screening (VS) proved to be a helpful tool for drug hit/ lead identification. Many studies have recently employed in silico exploration of large sets of natural products with the aid of online databases in attempt to discover new hits against potential molecular targets. Among which, a study by ul Qamar M. T. reported for structural insights into anti-viral phytochemicals/traditional Chinese medicinal compounds with in silico screening of 32297 natural products for their SARS-CoV-2 $3 \mathrm{CL}^{\text {pro }}$ inhibitory action. ${ }^{53}$ As shown in our in silico analysis, phenolic derivatives were the most prominent and active compounds against previous CoVs (Fig. 5). Thus, we subjected a library of phenolic metabolites, ${ }^{54}$ to a computer- aided virtual screening against the active site of the recently reported COVID-19 $\mathrm{M}^{\text {pro }}$ (PDB code: 5R7Z) based on highthroughput flexible docking technique for the sake of finding possible candidate acting as inhibitors for the newly emerged SARS-CoV2. Thirty four compounds were ranked by highest energy score and the poses that maintained the essential interactions. Twelve compounds were retrieved as the top-hits that fit into the $\mathrm{M}^{\text {pro }}$ target pocket (Table S2, ESI $\dagger$ ). Only three of these top candidates obey both Lipinski's and Veber's rules of drug-likeness (Fig. 8 and 9). The structure-activity relationship analyses of the final top-hits presented in Fig. 9(A) revealed that they shared convergent interactions with the active site's amino acid residues that are comparable with the previous CoV-main proteases inhibitors. All top hits exhibited hydrogen bonding interaction with Thr 190 via the hydroxyl phenolic group and the carbonyl oxygen of Thr 190 residue. Additional hydrogen bonding interactions were found to exist between ellagic acid (33) and Met-165 or isoxanthohumol (32) and Cys-145. Regarding van der Waal interactions, all the hits showed interaction with Gln-189, which is assumed to be essential for the activity (Fig. 9). Additionally, the presence of Gln-191, Glu166 and Cys-145 with some top-hits to form the hydrophobic subsite in other CoV $\mathrm{M}^{\text {pro }}$ which may create an extra van der Waal interactions. These essential interactions were found to be missing in low-scoring compounds. The selected hits with druglike properties are well reported to be abundant in many edible fruits such as raspberry and pomegranate. Hence, they are readily available for the in vitro investigation to validate them as potential anti-SARS CoV2 drug leads (Fig. 9). Regarding the possibility of the metabolic unstability of acetylglucopetunidin (31) and (2S)-isoxanthohumol (32), both compounds show the presence of acetylester or methoxy groups that could be easily hydrolyzed inside the human body. Accordingly, we redocked their respective metabolites (34 \& 35) to explore their inhibitory potential. Both metabolites were found to reserve the same hydrophobic and hydrogen bond interactions with His-41 and Gln-189 amino acid residues, respectively however, they gained an additional hydrogen bond interaction with Gln-189. Moreover, both metabolites bind with Cys-44 and Cys-145 via two hydrogen bond donors with binding affinity of $-7.147 \mathrm{kcal} \mathrm{mol}^{-1}$. The metabolite of $(2 S)$-isoxanthohumol (35) was found to bind with the same three amino acid residues i.e. Gln-189, Thr-190, and Glu-166, with a binding affinity of $-6.021 \mathrm{kcal} \mathrm{mol}^{-1}$, which was comparable to its parent compound (32), however, an extra hydrogen bond donor with Leu 141 was recorded (Fig. 9(D)).

\section{Concluding remarks}

The rapid identification of effective therapeutic interventions against COVID-19 is a major challenging issue nowadays. Taking into consideration that the development of new synthetic drugs is a time-consuming process, so repurposing the already known medications is the most convenient choice under the current situation. Hence, natural products can provide a valuable source for the rapid drug discovey of effective as well as safe anti-SARS $\mathrm{CoV}$ therapeutics. As has been 
illustrated in the current review, and other recently published reviews, a wide array of chemically-diverse natural products have proven to be excellent candidates as anti-SARS CoV, among which phenolic derivatives, viz. flavonoids were the most reported active agents, due to their promising pharmacokinetic profiles..$^{55}$

Being the most susceptible targets in $\mathrm{CoV}$, both $\mathrm{M}^{\text {pro }}$ and $\mathrm{PL}^{\text {pro }}$ of SARS-CoV in addition to a number of host-based proteases viz. cathepsins and furin, can be utilized for the sake of developing broad-spectrum anti-SARS CoV therapeutic agents that target multiple viral and non-viral proteins. Some phenolics such as tannins and flavonoids have exhibited a broad-spectrum activity not only against SARS-CoV but also other viruses ${ }^{56}$ Based on our findings, tPSA and molecular flexibility are the most essential descriptors that should be taken into consideration for selecting active and bioavailable phenolic compounds. The reported $\mathrm{IC}_{50}$ values of SARS natural products-inhibitors were mostly recorded in a micromolar range. However, more potent synthetic or semi-synthetic derivatives can be developed from the current scaffolds as they showed low to moderate molecular complexity. With the tremendous ongoing efforts to develop broad-spectrum antiviral therapeutics to combat coronaviruses and stop the rapid spread of COVID-19 worldwide, we hope that the current outbreak to settle down in a few months, as has been witnessed previously with SARS and MERS pandemics.

\section{Contributors}

AMS, AMA and ARK initiated the review. URA, HMH and MER developed the scope of the manuscript. AMS, AMA and ARK did the literature search and prepared the first draft. AMS designed the figures and interpreted the findings. URA, HZ, HMH and MER critically reviewed the data and draft. All authors subsequently modified the manuscript jointly. URA is the guarantor of the final version, which was read and approved by all the authors.

\section{Conflicts of interests}

We declare that we have no conflicts of interest.

\section{Acknowledgements}

The authors thank Nahda University in Beni Suef (NUB), Minia, Beni Suef Universities and Arab Academy for Science, Technology and Maritime Transport for supporting this work. We thank Jörn Piel (Institute of Microbiology, ETH Zürich, Zürich, Switzerland), Prof. Hossam Eldin Elmalahi (Nahda University, Beni Suef, Egypt) and Prof. Emad Hamdi Ghoz (Deraya University, New Minia, Egypt) for their support and fruitful discussion.

\section{References}

1 E. De Wit, N. Van Doremalen, D. Falzarano and V. J. Munster, Nat. Rev. Microbiol., 2016, 14, 523-534.
2 V. Kumar, Y. S. Jung and P. H. Liang, Expert Opin. Ther. Pat., 2013, 23, 1337-1348.

3 V. Thiel, K. A. Ivanov, Á. Putics, T. Hertzig, B. Schelle, S. Bayer, B. Weißbrich, E. J. Snijder, H. Rabenau, H. W. Doerr, A. E. Gorbalenya and J. Ziebuhr, J. Gen. Virol., 2003, 84, 2305-2315.

4 K. Anand, J. Ziebuhr, P. Wadhwani, J. R. Mesters and R. Hilgenfeld, Science, 2003, 300, 1763-1767.

5 E. J. Snijder, P. J. Bredenbeek, J. C. Dobbe, V. Thiel, J. Ziebuhr, L. L. M. Poon, Y. Guan, M. Rozanov, W. J. M. Spaan and A. E. Gorbalenya, J. Mol. Biol., 2003, 331, 991-1004.

6 S. van Boheemen, M. de Graaf, C. Lauber, T. M. Bestebroer, V. S. Raj, A. M. Zaki, A. D. M. E. Osterhaus, B. L. Haagmans, A. E. Gorbalenya, E. J. Snijder and R. A. M. Fouchier, mBio, 2012, 3, 1-9.

7 K. S. Chan, S. T. Lai, C. M. Chu, E. Tsui, C. Y. Tam, M. M. L. Wong, M. W. Tse, T. L. Que, J. S. M. Peiris, J. Sung, V. C. W. Wong and K. Y. Yuen, Hong Kong Med. J., 2003, 9, 399-406.

8 B. Cao, Y. Wang, D. Wen, W. Liu, J. Wang, G. Fan, L. Ruan, B. Song, Y. Cai, M. Wei, X. Li, J. Xia, N. Chen, J. Xiang, T. Yu, T. Bai, X. Xie, L. Zhang, C. Li, Y. Yuan, H. Chen, H. Li, H. Huang, S. Tu, F. Gong, Y. Liu, Y. Wei, C. Dong, F. Zhou, X. Gu, J. Xu, Z. Liu, Y. Zhang, H. Li, L. Shang, K. Wang, K. Li, X. Zhou, X. Dong, Z. Qu, S. Lu, X. Hu, S. Ruan, S. Luo, J. Wu, L. Peng, F. Cheng, L. Pan, J. Zou, C. Jia, J. Wang, X. Liu, S. Wang, X. Wu, Q. Ge, J. He, H. Zhan, F. Qiu, L. Guo, C. Huang, T. Jaki, F. G. Hayden, P. W. Horby, D. Zhang and C. Wang, N. Engl. J. Med., 2020, 382(19), 1787-1799.

9 Y. M. Báez-Santos, S. J. Barraza, M. W. Wilson, M. P. Agius, A. M. Mielech, N. M. Davis, S. C. Baker, S. D. Larsen and A. D. Mesecar, J. Med. Chem., 2014, 57, 2393-2412.

10 K. Ratia, S. Pegan, J. Takayama, K. Sleeman, M. Coughlin, S. Baliji, R. Chaudhuri, W. Fu, B. S. Prabhakar, M. E. Johnson, S. C. Baker, A. K. Ghosh and A. D. Mesecar, Proc. Natl. Acad. Sci. U. S. A., 2008, 105, 16119-16124.

11 C. M. Booth, L. M. Matukas, G. A. Tomlinson, A. R. Rachlis, D. B. Rose, H. A. Dwosh, S. L. Walmsley, T. Mazzulli, M. Avendano, P. Derkach and I. E. Ephtimios, J. Am. Med. Assoc., 2003, 289, 2801-2809.

12 J. A. Tanner, B. J. Zheng, J. Zhou, R. M. Watt, J. Q. Jiang, K. L. Wong, Y. P. Lin, L. Y. Lu, M. L. He, H. F. Kung, A. J. Kesel and J. D. Huang, Chem. Biol., 2005, 12, 303-311. 13 L. Wilson, P. Gage and G. Ewart, Virology, 2006, 353, 294306.

14 W. Li, M. J. Moore, N. Vasllieva, J. Sui, S. K. Wong, M. A. Berne, M. Somasundaran, J. L. Sullivan, K. Luzuriaga, T. C. Greeneugh, H. Choe and M. Farzan, Nature, 2003, 426, 450-454.

15 J. Gao, G. Lu, J. Qi, Y. Li, Y. Wu, Y. Deng, H. Geng, H. Li, Q. Wang, H. Xiao, W. Tan, J. Yan and G. F. Gao, J. Virol., 2013, 87, 13134-13140.

16 Z. Qian, S. R. Dominguez and K. V. Holmes, PLoS One, 2013, 8, e76469. 
17 K. Shirato, M. Kawase and S. Matsuyama, J. Virol., 2013, 87, 12552-12561.

18 C. Burkard, M. H. Verheije, B. L. Haagmans, F. J. van Kuppeveld, P. J. M. Rottier, B.-J. Bosch and C. A. M. de Haan, J. Virol., 2015, 89, 4434-4448.

19 A. K. Ghosh, K. Xi, M. E. Johnson, S. C. Baker and A. D. Mesecar, Annu. Rep. Med. Chem., 2006, 41, 183-196.

20 L. Yi, Z. Li, K. Yuan, X. Qu, J. Chen, G. Wang, H. Zhang, H. Luo, L. Zhu, P. Jiang, L. Chen, Y. Shen, M. Luo, G. Zuo, J. Hu, D. Duan, Y. Nie, X. Shi, W. Wang, Y. Han, T. Li, Y. Liu, M. Ding, H. Deng and X. Xu, J. Virol., 2004, 78, 11334-11339.

21 T. Y. Ho, S. L. Wu, J. C. Chen, C. C. Li and C. Y. Hsiang, Antiviral Res., 2007, 74, 92-101.

22 A. O. Adedeji, W. Severson, C. Jonsson, K. Singh, S. R. Weiss and S. G. Sarafianos, J. Virol., 2013, 87, 8017-8028.

23 C. W. Lin, F. J. Tsai, C. H. Tsai, C. C. Lai, L. Wan, T. Y. Ho, C. C. Hsieh and P. D. L. Chao, Antiviral Res., 2005, 68, 36-42.

24 L. Zhou, Y. Liu, W. Zhang, P. Wei, C. Huang, J. Pei, Y. Yuan and L. Lai, J. Med. Chem., 2006, 49, 3440-3443.

25 C. N. Chen, C. P. C. Lin, K. K. Huang, W. C. Chen, H. P. Hsieh, P. H. Liang and J. T. A. Hsu, Evid. base Compl. Alternative Med., 2005, 2, 209-215.

26 N. Fusetani, M. Fujita, Y. Nakao, S. Matsunaga and R. W. Van Soest, Bioorg. Med. Chem. Lett., 1999, 9, 3397-3402.

27 Y. akao, M. Fujita, K. Warabi, S. Matsunaga, N. Fusetani and A. Miraziridine, J. Am. Chem. Soc., 2000, 122, 10462-10463.

28 S. Yang, S. J. Chen, M. F. Hsu, J. D. Wu, C. T. K. Tseng, Y. F. Liu and W. C. Chen, J. Med. Chem., 2006, 49, 4971-4980.

29 L. Chen, J. Li, C. Luo, H. Liu, W. Xu, G. Chen and H. Jiang, Bioorg. Med. Chem., 2006, 14, 8295-8306.

30 Y. B. Ryu, H. J. Jeong, J. H. Kim, Y. M. Kim, J. Y. Park, D. Kim and M. C. Rho, Bioorg. Med. Chem., 2010, 18, 7940-7947.

31 A. O. Adedeji and S. G. Sarafianos, Curr. Opin. Virol., 2014, 8, 45-53.

32 J. Y. Park, J. H. Kim, J. M. Kwon, H. J. Kwon, H. J. Jeong, Y. M. Kim and Y. B. Ryu, Bioorg. Med. Chem., 2013, 21, 3730-3737.

33 T. T. H. Nguyen, H. J. Woo, H. K. Kang, V. D. Nguyen, Y. M. Kim, D. W. Kim and D. Kim, Biotechnol. Lett., 2012, 34, 831-838.

34 Y. Yang, M. S. Islam, J. Wang, Y. Li and X. Chen, Int. J. Biol. Sci., 2020, 16, 1708.

35 M. S. Yu, J. Lee, J. M. Lee, Y. Kim, Y. W. Chin, J. G. Jee and Y. J. Jeong, Bioorg. Med. Chem. Lett., 2012, 22, 4049-4054.

36 C. C. Wen, Y. H. Kuo, J. T. Jan, P. H. Liang, S. Y. Wang, H. G. Liu and C. C. Hou, J. Med. Chem., 2007, 50, 4087-4095.
37 Y. B. Ryu, S. J. Park, Y. M. Kim, J. Y. Lee, W. D. Seo, J. S. Chang and W. S. Lee, Bioorg. Med. Chem. Lett., 2010, 20, 1873-1876.

38 P. Hamill, D. Hudson, R. Y. Kao, P. Chow, M. Raj, H. Xu and F. Jean, Biol. Chem., 2006, 387, 1063-1074.

39 J. K. Cho, M. J. Curtis-Long, K. H. Lee, D. W. Kim, H. W. Ryu, H. J. Yuk and K. H. Park, Bioorg. Med. Chem., 2013, 21, 30513057.

40 J. Y. Park, J. H. Kim, Y. M. Kim, H. J. Jeong, D. W. Kim, H. H. Park and Y. B. Ryu, Bioorg. Med. Chem., 2012a, 20, 5928-5935.

41 J. Y. Park, H. J. Jeong, J. H. Kim, Y. M. Kim, S. J. Park, D. Kim and Y. B. Ryu, Biol. Pharm. Bull., 2012, 35, 2036-2042.

42 H. Wang, S. Xue, H. Yang and C. Chen, Virol. Sin., 2016, 31, 24-30.

43 J. Y. Park, J. A. Ko, D. W. Kim, Y. M. Kim, H. J. Kwon, H. J. Jeong and Y. B. Ryu, J. Enzyme Inhib. Med. Chem., 2016, 31, 23-30.

44 J. Y. Park, H. J. Yuk, H. W. Ryu, S. H. Lim, K. S. Kim, K. H. Park, Y. B. Ryu and W. S. Lee, J. Enzyme Inhib. Med. Chem., 2017, 32, 504-512.

45 Y. C. Tsai, C. L. Lee, H. R. Yen, Y. S. Chang, Y. P. Lin, S. H. Huang and C. W. Lin, Biomolecules, 2020, 10, 366.

46 Y. H. Song, D. W. Kim, M. J. Curtis-Long, H. J. Yuk, Y. Wang, N. Zhuang and K. H. Park, Biol. Pharm. Bull., 2014, 37, 10211028.

47 D. W. Kim, K. H. Seo, M. J. Curtis-Long, K. Y. Oh, J. W. Oh, J. K. Cho and K. H. Park, J. Enzyme Inhib. Med. Chem., 2014, 29, 59-63.

48 J. y. Park, H. J. Yuk, H. W. Ryu, S. H. Lim, K. S. Kim, K. H. Park and W. S. Lee, J. Enzyme Inhib. Med. Chem., 2017, 32, 504-512.

49 S. Schwarz, D. Sauter, K. Wang, R. Zhang, B. Sun, A. Karioti and W. Schwarz, Planta Med., 2014, 80, 177-182.

50 C. A. Lipinski, Drug Discov. Today Technol., 2004, 1, 337-341.

51 D. F. Veber, S. R. Johnson, H. Y. Cheng, B. R. Smith, K. W. Ward and K. D. Kopple, J. Med. Chem., 2002, 45, 2615-2623.

52 G. Wolber and T. Langer, J. Chem. Inf. Model, 2005, 45, 160169.

53 M. T. ul Qamar, S. M. Alqahtani, M. A. Alamri and L. L. Chen, J. Pharm. Anal., 2020, DOI: 10.1016/j.jpha.2020.03.009.

54 V. Neveu, J. Perez-Jiménez, F. Vos, V. Crespy, L. du Chaffaut, L. Mennen and A. Scalbert, Database, 2010, 2010, bap024.

55 M. T. Islam, C. Sarkar, D. M. El-Kersh, S. Jamaddar, S. J. Uddin, J. A. Shilpi and M. S. Mubarak, Phytother Res., 2020, 1-22.

56 O. S. Martins, I. A. Santos, D. M. Oliveira, R. V. Grosche and A. C. G. Jardim, Viruses, 2020, 12, 272. 